\title{
VOCATIONAL STUDENTS' PERCEPTION OF ONLINE LEARNING DURING THE COVID-19 PANDEMIC
}

\author{
Hilma Erliana ${ }^{1}$, Safrizal ${ }^{2}$, Rahmad Nuthihar ${ }^{3}$, Luthfi $^{4}$, Wahdaniah ${ }^{5}$, Ilham Jaya ${ }^{6}$, RN Herman ${ }^{7, *}$ \\ 1, 2, 3,4 Akademi Komunitas Negeri Aceh Barat, Komplek STTU Alue Peunyareng, Ujong Tanoh Darat, Meureubo, Kabupaten \\ Aceh Barat, Aceh 23615, Indonesia \\ ${ }^{5,6}$ Department of Mechanical engineering, Politeknik Negeri Lhokseumawe, Jl. Banda Aceh-Medan Km. 280,3, Buketrata \\ Mesjid Punteut, Blang Mangat, Lhokseumawe 24301, Indonesia \\ ${ }^{7}$ Department of Bahasa Indonesia Education, Faculty of Teacher Training and Education, Universitas Syiah Kuala, Jalan \\ Tgk. Hasan Krueng Kalee, Darussalam, Banda Aceh 23111, Indonesia \\ E-mail: herman_rn@unsyiah.ac.id* \\ *Corresponding Author
}

\begin{abstract}
COVID-19 pandemic impacts on vocational education. Lectures that were originally conducted face-toface learning are diverted to online learning to avoid the spread of the pandemic. Online learning is very difficult to apply for courses conducted in the laboratory. This study discusses vocational students' responses to the practice of online learning during the COVID-19 pandemic. Data were collected through a questionnaire created on Google form consisting of 20 questions. The questionnaire used a Likert scale to find out the attitudes and students' perceptions of the implementation of online learning. The number of research respondents was 107 people consisting of 45 respondents from the West Aceh State Community Academy and 62 respondents from Lhokseumawe State Polytechnic, Aceh, Indonesia. The results of this study found that $59.81 \%$ of students disagree with online learning. The results also showed a score of $76.95 \%$ of the students agree that internet access is the main obstacle in online learning. However, students' satisfaction with the current online learning system for students shows a score of $67.50 \%$. Opinions related to online learning from 107 respondents showed that $45.42 \%$ of them less agree if online learning is still applied when the COVID-19 pandemic ends.
\end{abstract}

Keywords: community college, COVID-19, online learning, students' perception, TVET

\section{INTRODUCTION}

In early 2020, the COVID-19 pandemic rapidly spread across the globe. The virus continues to move rapidly and it affects all fields such as the economy, politics, government [1] and it also had deep impacts not only in learning and education but also on teachers and students [2]. To avoid the risk of COVID-19 transmission, Indonesia implements stay-athome orders and travel restrictions to suggest worship, work and learn from home [3]. As schools closed, various policies were issued by the government to optimize learning activities dealing with the COVID-19 pandemic. Learning that was originally done face-to-face, has now turned into distance learning by optimizing various digital devices and applications.

However, online learning becomes a challenge in vocational education since vocational education focuses more on skills in a particular field of study and balanced them with general knowledge, and attitudes [4], [5]. The curriculum in vocational school takes more learning parts in laboratories and field works or internships [6], [7]. Skills mastery is an absolute requirement that must be possessed by graduates from vocational institutions. Besides obtaining a diploma, graduates from vocational colleges also receive certificates of expertise to prove mastery of the material during lectures, so that career considerations become a reason for students to continue on vocational higher education [8], [9]. This condition affected the performance of vocational education that prepares graduates to work, especially in terms of curriculum development, adjustment of learning tools, and the readiness of the educators [10].

The COVID-19 pandemic impacts more in vocational education especially at higher education such as the State Community Academy and Polytechnic. At the State Community Academy, the expected learning output is skills referring to the Indonesian 
Qualifications Framework (IQF) in levels 3 to 4 because it performs education for one year and two years associate degree programs. While at the Polytechnic, the IQF level is at level 5 for three-year associate degree programs and level 6 for bachelor degree programs [11]. Lecturers in these institutions are demanded to optimize mastery of skills that used to be delivered with practices in the laboratory or fields switched to online learning with limited technological facilities. Several media and applications used in online lectures in Indonesia are Google Classroom, WhatsApp, Email, Zoom, and Moodle, [12], [13]. Lecturers expected that the use of that learning media can implement effective learning methods by considering the background, age, and tools used by students to study online [14]-[16]. Online learning should be equipped with complete facilities thus communication between lecturers and students can be carried out effectively [17], [18]. The utilization of technology should be able to optimize learning in vocational education by using Virtual Reality (VR), Augmented Reality (AR), and the Internet of Things (IoT) [19].

Various studies on this issue have been conducted, such as Gunawan et.al [20] who used a survey method with 212 lecturers of LPTK. The result showed that the problems encountered in online learning are $78 \%$ due to limited and expensive internet packages, $53 \%$ due to the lack of internet access, $46 \%$ caused by the lack of student attendance, $40 \%$ caused by students are not used to online learning, $24 \%$ lecturers felt difficult correcting student' assignments. This study is discussed only based on the perspective of the lecturer, it does not involve students [20].

Meanwhile, Firman \& Rahman [21] explained the effectiveness of online learning only based on the results of interviews and does not use a questionnaire. The result of his research showed that online learning has an impact on student learning independence that is supported by the availability of online learning facilities. This research was conducted in academic education [21]. In addition, research on learning satisfaction during the COVID-19 pandemic has also been conducted by researchers in Aceh. The results of these studies concluded that throughout the COVID-19 pandemic, teachers from remote areas in Aceh, with all the limitations, faced different challenges in introducing distance learning through online learning, as explained by the teacher [22].

Therefore, the objective of this study is to provide an overview of the vocational students' perceptions of the effectiveness of online learning since $60 \%$ of their previous learning process is carried out through direct practices in laboratories and the fields. Students' perceptions are crucial variables to be used in evaluating the learning process to increase students' learning experience [5]. Analysis in online learning is required to have a better understanding of student learning styles and comfort in online learning [23].

This study is significant because there has never been such a dramatic change in the use of online learning caused by the COVID-19 pandemic, especially in vocational education. The results of this study can be used as an essential reference to design online learning for vocational education based on the students' perception.

\section{METHOD}

This study used a quantitative survey research design. The data were collected through a questionnaire created on Google Form. The questionnaire consists of 20 questions related to online learning. The questionnaires were distributed through WhatsApp Group which is sent to class leaders to be forwarded to all students. The number of research respondents was 107 people consisting of 45 respondents from the West Aceh State Community Academy and 62 respondents from Lhokseumawe State Polytechnic. Those respondents are classified into two classes, namely class 2018 and 2019 This study was conducted at the West Aceh State Community Academy and Lhokseumawe State Polytechnic. The two schools are state institutions under the Ministry of Education and 
Culture of the Directorate General of Vocational Education.

Research subjects were 107 students in the class of 2018 and 2019 who are recorded in the university database. Data were collected in one week (18 to 23 May 2020). The schedule was chosen because the West Aceh State Community Academy closed online lectures from April $18^{\text {th }}$ to June $1^{\text {st }}, 2020$. While the Lhokseumawe State Polytechnic closed online lectures from April $22^{\text {nd }}$ until June $2^{\text {nd }}, 2020$. To prove the validity of respondents, the respondents' data were examined with the data in Higher Education Database, Ministry of Education and Culture on June $2^{\text {nd }}, 2020$

The calculation of questionnaire results used the Likert Scale method. Likert scale is used to calculate respondents' perceptions and/or opinions about an event based on a predetermined statement [24]-[26]. Table 1 presents the calculation of the scale score

Table 1. Calculation of Scale Scores

\begin{tabular}{lll}
\hline \multicolumn{1}{c}{ Answers } & Score \\
\hline SD & 1 & \\
D & 2 & \\
LA & 3 & \\
A & 4 \\
SA & 5 & \\
\hline
\end{tabular}

Information

$\mathrm{SD} \quad=$ Strongly Disagree

$\mathrm{D} \quad=$ Disagree

LA $=$ Less Agree

$\mathrm{A}=$ Agree

SA $\quad=$ Strongly Agree

Interpretation of calculation scores is as follows: $\mathrm{Y}=$ Highest Likert Scale $\mathrm{x}$ number of respondents

$\mathrm{X}=$ Lowest Likert Scale $\mathrm{x}$ number of respondents

Index Formula $\%=\frac{\text { Total Score }}{\mathrm{Y} \times 100}$

After determining the value of $\mathrm{Y}$, then the calculation uses the index formula to find out the interval (distance range) and interpretation of percent to know the assessment by finding the percent score interval (I). The index formula is elaborated on in each questionnaire statement [27]. Table 2 shows the criteria for interpretation of scores based on intervals

Interval Formulas: $\mathrm{I}=\frac{100}{\begin{array}{c}\text { Total of Score } \\ \text { (Likert) }\end{array}}$

Table 2. The Criteria for Interpretation of Scores Based on Intervals

\begin{tabular}{cl}
\hline Criteria & \multicolumn{1}{c}{ Interpretation } \\
\hline $0 \%$ to $19.99 \%$ & Strongly Disagree \\
$20 \%$ to $39.99 \%$ & Disagree \\
$40 \%$ to $59.99 \%$ & Quite Agree \\
$60 \%$ to $79.99 \%$ & Agree \\
$80 \%$ to $100 \%$ & Strongly Agree \\
\hline
\end{tabular}

\section{RESULTS AND DISCUSSION}

There were 20 statements answered by 107 respondents consisting of students from the West Aceh State Community Academy and Lhokseumawe State Polytechnic. The respondents were divided into two batches, namely the class of 2018 and 2019. The respondents are explained in Figure 1.

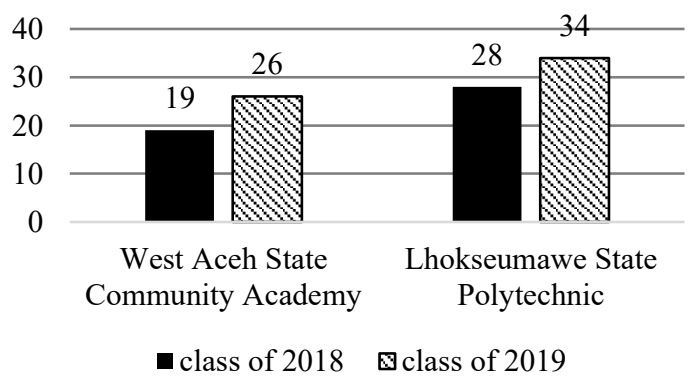

Figure 1. Respondents of the Study

The questions distributed to respondents were divided into 3 indicators in measuring the level of quality in online learning applied during the COVID 19 pandemic especially in vocational education in the province of Aceh, Indonesia. The indicators consist of the effectiveness of online learning for students, the problem of internet access in online learning, and the online learning system for students.

The first indicator is the effectiveness of online learning for students. In this indicator, 
there are 6 statements about the effectiveness of online learning for students in which each statement filled by 107 respondents thus this whole section collected 642 responses. Those who answered SD, D, LA, A, and SA were 56, $138,238,176$, and 34 respondents respectively. The data and data processing are presented in Table 3 and Table 4 respectively.

Table 3. The Effectiveness of Online Learning for students

\begin{tabular}{|c|c|c|c|c|c|c|}
\hline No & Questions & $\mathrm{SD}$ & $\mathrm{D}$ & LA & $\mathrm{A}$ & SA \\
\hline 1 & $\begin{array}{l}\text { Online learning } \\
\text { is flexible so you } \\
\text { can do more } \\
\text { activities at one } \\
\text { time }\end{array}$ & 3 & 14 & 27 & 61 & 2 \\
\hline 2 & $\begin{array}{l}\text { Online learning } \\
\text { promotes } \\
\text { innovation and } \\
\text { creative ideas }\end{array}$ & 8 & 20 & 42 & 28 & 9 \\
\hline 3 & $\begin{array}{l}\text { Online learning } \\
\text { is very beneficial } \\
\text { for students }\end{array}$ & 9 & 21 & 47 & 25 & 5 \\
\hline 4 & $\begin{array}{l}\text { Material given } \\
\text { by lecturers can } \\
\text { be practiced } \\
\text { directly at home }\end{array}$ & 16 & 29 & 41 & 17 & 4 \\
\hline 5 & $\begin{array}{l}\text { There are no } \\
\text { difficulties in } \\
\text { online learning }\end{array}$ & 4 & 25 & 40 & 28 & 10 \\
\hline \multirow[t]{2}{*}{6} & $\begin{array}{ll}\text { Learning } & \text { from } \\
\text { home is a } & \text { good } \\
\text { decision. } & \end{array}$ & 16 & 29 & 41 & 17 & 4 \\
\hline & $\begin{array}{c}\text { Total } \\
\text { Respondents }\end{array}$ & 56 & 138 & 238 & 176 & 34 \\
\hline
\end{tabular}

Table 4. Data Processing of the Effectiveness of Online Learning for Students

\begin{tabular}{ccc}
\hline Answer Scale & T $\times$ Pn & Total \\
\hline SD & $56 \times 1$ & 56 \\
D & $138 \times 2$ & 276 \\
LA & $238 \times 3$ & 714 \\
A & $176 \times 4$ & 704 \\
SA & $34 \times 5$ & 170 \\
\hline
\end{tabular}

From the data, the total score calculation is $56+276+714+704+110=1920$. The highest number of scales for "Strongly Agree" items is $5 \times 642=3210$, while the lowest scale for "Strongly Disagree" items is 1 x $642=642$.

$$
\begin{aligned}
\text { Index Formula } \% & =\frac{\text { Total Score }}{\mathrm{Y} \times 100} \\
& =\frac{1920}{3210 \times 100} \\
& =59.81 \%
\end{aligned}
$$

Based on these findings, the final result about the effectiveness of online learning for students showed a percentage of $59.81 \%$ in the interval scale of "Less Agree". It can be interpreted that the respondents considered that online learning that had been carried out was ineffective.

Notably, this is because vocational education gives more emphasis on the mastery of certain applied skills. It is ineffective for online learning to be implemented on vocational campuses in which there are more direct practices in the fields than academic education that put points on mastering the development of theoretical knowledge. Vocational education aims to equip students with applied or practical skills. The curriculum composition includes $60 \%$ practice and $40 \%$ theory. Whereas, in academic education, students are directed to master science or theory. The curriculum composition includes $60 \%$ theory and $40 \%$ practice. Therefore, online learning is not suitable for vocational education.

These results are in contrast with Firman et al. [21] who suggested that online learning provided flexibility in its implementation, thus it encourages students to be independent in learning and can motivate them to learn more actively. Firman et al. [21] also stated that online learning was also able to foster student learning independence. Learning without direct guidance from lecturers makes students independently look for information about course materials and assignments given to them. However, this is because the research subjects are addressed to Biology students at the faculty of teaching and education who master more the materials based on theory rather than practice.

On the other hand, the results of this study tie well with Syauqi et al. [5] who reported that teachers of vocational schools are struggling to meet student standards when it comes to handling online learning. Students believe that online learning cannot provide better experience and productivity in mastering skills and competencies in vocational education. When the subject is related to specific procedures and is 
practice-based, online learning can be difficult. Also, teachers find it difficult to notice nonverbal behavioral signals and assess whether students are disengaged, irritated, or disinterested in engagement without face-to-face experiences [28].

A similar conclusion was reached by Nambiar [29] who conclude that students thought the online classes were of poor quality. Technical issues, a lack of structure, disruptions in class flow, difficulties in clarifying doubts, and a lack of interest and motivation to attend classes were all major factors that reduced the efficacy of online classes.

The second indicator focused on the problem of internet access in online learning. There are 6 statements regarding the problem of internet access in online learning in which each statement filled by 107 respondents. Therefore, this whole section collected 642 responses. Those who answered SD, D, LA, A, and SA were 20, 52, 119, 266, and 185 respondents respectively. The data and data processing are presented in Table 5 and Table 6 respectively.

From the data, the total score calculations obtained is $20+104+357+1064+925=2470$. The highest number of scales for "Strongly Agree" items is 5 x $642=3210$, while the lowest scale for "Strongly Disagree" items is 1 x $642=642$.

$$
\begin{aligned}
\text { Index Formula } \% & =\frac{\text { Total Score }}{\mathrm{Y} \times 100} \\
& =\frac{2470}{3210 \times 100} \\
& =76.95 \%
\end{aligned}
$$

Based on the calculation, the result of questionnaires related to problems of internet access in online learning shows that $79.95 \%$ of students agree. It can be interpreted that the respondent considers that one of the main obstacles affecting online learning is internet network access.

The reason for this is because students experience limited internet access which is expensive and poor access due to the location of each student. Most of them find it difficult to reach internet signals. Various models and platforms such as participating in learning via zoom or video conferencing used by lecturers in online learning certainly require a lot of internet packages. This certainly makes it difficult for students to follow the material and interact well in learning implementation. This is consistent with what has been found in previous studies [20], [21]. Gunawan et al. [20] found that 78\% of the students answered that online learning problems came from limited and expensive internet packages. The success of e-learning is dependent on a reliable Internet connection. At several levels, adequate bandwidth is needed to ensure proper downloading [30].

\begin{tabular}{lllllll} 
Table 5. Internet Access in Online Learning \\
\hline No & \multicolumn{1}{c}{ Questions } & SD & D & LA & A & SA \\
\hline 1 & $\begin{array}{l}\text { Less internet } \\
\text { quota is a barrier } \\
\text { for students }\end{array}$ & 4 & 11 & 34 & 57 \\
2 & & & & \\
The quality of the & 4 & 4 & 23 & 48 & 28 \\
internet network \\
around the house \\
does not support \\
online learning \\
3
\end{tabular}

Table 6. Data Processing of Internet Access in Online Learning

\begin{tabular}{ccc}
\hline Answer Scale & T $\times$ Pn & Total \\
\hline SD & $20 \times 1$ & 20 \\
D & $52 \times 2$ & 104 \\
LA & $119 \times 3$ & 357 \\
A & $266 \times 4$ & 1064 \\
SS & $185 \times 5$ & 925 \\
\hline
\end{tabular}


The third indicator is the online learning system for students. In this part, there are 7 statements about the online learning system for students in which each statement filled by 107 respondents. Then this whole section comes up with 749 respondents. Those who answered SD, D, LA, A, and SA were 45, 108, 206, 301, and 89 respondents respectively. The data and data processing are presented in Table 7 and Table 8 respectively.

From the results, the total score of calculation is $45+216+618+1204+445=2528$. The highest number of scales for "Strongly Agree" items is $5 \times 749=3745$, while the lowest scale for "Strongly Disagree" items is $1 \times 749=$ 749.

$$
\begin{aligned}
\text { Index Formula } \% & =\frac{\text { Total Score }}{\mathrm{Y} \times 100} \\
& =\frac{3745}{2528 \times 100} \\
& =67.50 \% \%
\end{aligned}
$$

Based on the calculation, the result of questionnaires related to online learning systems for students' problems shows that $67.50 \%$ of students agree. It can be interpreted that the respondents agreed that the learning system or method that was currently applied as appropriate.

According to students, the methods that have been used by the lecturers in providing online learning materials are feasible. The learning media that are usually used are WAG, Google Classroom, Zoom Application, and Email. Online learning during the social distancing period provided several innovations, namely various types of online learning models and platforms.

Students require technology literacy to develop better online learning. In the era of industrial revolution 4.0, students should be able to use and develop digital technology in the learning process. Likewise, according to Pratiwi [13], learning activities using learning methods available on the Play Store / Application Store such as Google Classroom, Schoology, Zoom,

\begin{tabular}{|c|c|c|c|c|c|c|}
\hline No & Questions & SD & $\mathrm{D}$ & LA & $\mathrm{A}$ & SA \\
\hline 1 & $\begin{array}{lr}\text { Learning } & \\
\text { material } & \\
\text { uploaded } & \text { by } \\
\text { lecturers on } \\
\text { online learning } \\
\text { was good }\end{array}$ & 2 & 6 & 33 & 54 & 12 \\
\hline 2 & $\begin{array}{l}\text { Learning } \\
\text { material taught } \\
\text { can be } \\
\text { understood } \\
\text { deeply through } \\
\text { online learning }\end{array}$ & 7 & 20 & 42 & 32 & 6 \\
\hline 3 & $\begin{array}{l}\text { Students feel } \\
\text { laboratory } \\
\text { subjects difficult } \\
\text { because they } \\
\text { have to study via } \\
\text { online meeting }\end{array}$ & 3 & 6 & 7 & 52 & 39 \\
\hline 4 & $\begin{array}{l}\text { The objects } \\
\text { around the house } \\
\text { can be used for } \\
\text { practicing the } \\
\text { material } \\
\text { provided by } \\
\text { lecturers }\end{array}$ & 6 & 29 & 39 & 31 & 2 \\
\hline 5 & $\begin{array}{l}\text { Online learning } \\
\text { makes it easier } \\
\text { for students to } \\
\text { ask questions } \\
\text { that are not } \\
\text { understood }\end{array}$ & 18 & 28 & 31 & 28 & 2 \\
\hline 6 & $\begin{array}{l}\text { Online learning } \\
\text { makes lecturers } \\
\text { give re more } \\
\text { assignments to } \\
\text { students }\end{array}$ & 4 & 13 & 20 & 49 & 21 \\
\hline 7 & $\begin{array}{l}\text { Informing } \\
\text { students through } \\
\text { print media and } \\
\text { social media } \\
\text { about the } \\
\text { procedures for } \\
\text { implementing } \\
\text { online learning } \\
\text { has been } \\
\text { implemented }\end{array}$ & 5 & 6 & 34 & 55 & 7 \\
\hline & $\begin{array}{c}\text { Total } \\
\text { Respondents }\end{array}$ & 45 & 108 & 206 & 301 & 89 \\
\hline
\end{tabular}
and Edmodo is very good and effective.
Table 7. Online Learning System for Students

Table 8. Data Processing of Online Learning System for Students

\begin{tabular}{ccc}
\hline Answer Scale & T x Pn & Total \\
\hline SD & $45 \times 1$ & 45 \\
D & $108 \times 2$ & 216 \\
LA & $206 \times 3$ & 618 \\
A & $301 \times 4$ & 1204 \\
SA & $89 \times 5$ & 445 \\
\hline
\end{tabular}

The fourth indicator is the students' opinions about online learning. This is to find out 
the respondent's opinion whether they agree if the online learning model is still applied when the COVID-19 pandemic ends. 107 respondents answered this statement. The results are presented in Figure 2.

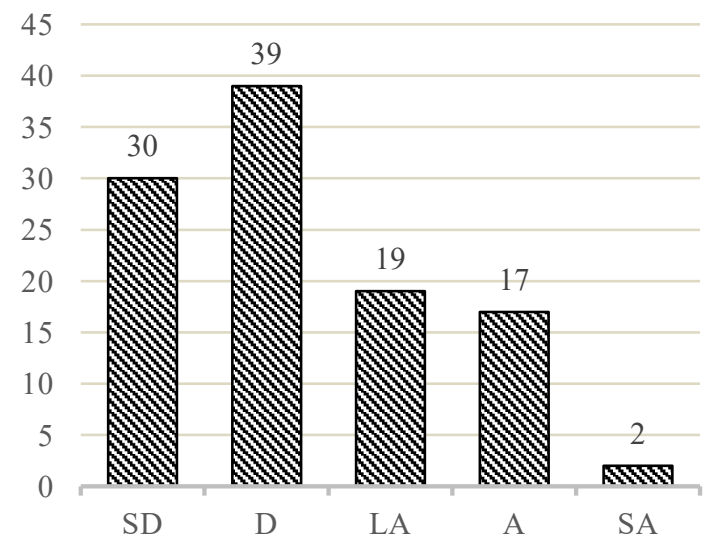

Figure 2. Respondents' Opinion on Online Learning

The data indicate that 39 respondents answered that they did not agree if online learning is applied when the COVID 19 pandemic ends. Moreover, 30 respondents even answered that they strongly disagree if online learning is still applied. The highest answer from respondents is disagree to apply online learning when the pandemic ends. That is because the online learning model is less effective in the time of the COVID-19 pandemic. It is noted that students disagree if online learning is applied in Vocational Higher Education. As discussed, this is due to this time of crisis, Covid-19 has affected the field of education, resulting in a decline in learning activities and a reduction in the presence of teachers in the classroom [31]. Therefore, teachers and stakeholders should proactively promote and support the online education method by ensuring that learning continues for all students around the country as the best option for the continuity of learning processes by minimalizing the obstacles, particularly during the COVID-19 pandemic crisis. Online learning requires improvement in terms of reliable and affordable internet, infrastructure, technological advancements, and the provision of well-guided technical support.

\section{CONCLUSION}

This study indicates that although lectures have applied various feasible online learning media, vocational students still consider online learning is still less effective to apply in vocational education because vocational education implements more learning approaches in the fields (practice) than theoretical learning. Furthermore, the crucial problem faced in online learning is internet access, in which the majority of students are not able to purchase adequate internet packages, and others feel difficult to access the internet connection because they live mostly in rural areas. It is noted that students disagree if online learning is applied in Vocational Higher Education in Aceh.

To optimize online lectures at higher education institutions, the government is expected to provide facilities such as learning videos related to mastering vocational skills. This can be conducted by collaborating between the Ministry of Education's Film Censorship Body, the National Professional Certification Agency (BNSP), Vocational Training Centres (BLK), universities (involving lecturers, instructors, and technicians), the business and industrial world, and other institution training under the Ministry of Education and Culture. Digital material availability must be urgently carried out by the government especially in the COVID-19 pandemic situation.

\section{REFERENCES}

[1] R. Tosepu et al., "Correlation between weather and Covid-19 pandemic in Jakarta, Indonesia," Sci. Total Environ., vol. 725, p. 138436, 2020, doi: 10.1016/j.scitotenv.2020.138436.

[2] M. Aresta, A. Fernandes, and A. I. Ribeiro, "From face-to-face to online learning: Covid-19 and the emergence of ubiquitous learning scenarios," 2020, doi: 10.21125/iceri.2020.2100.

[3] Ihsanuddin, "Jokowi: Kerja dari Rumah, Belajar dari Rumah, Ibadah di Rumah 
Perlu Digencarkan,” Kompas, Indonesia, 2020.

[4] M. E. Ismail et al., "Factors that influence students' learning: An observation on vocational college students," J. Tech. Educ. Train., vol. 11, no. 1, pp. 93-99, 2019, doi: 10.30880/jtet.2019.11.01.12.

[5] K. Syauqi, S. Munadi, and M. B. Triyono, "Students' perceptions toward vocational education on online learning during the COVID-19 pandemic," Int. J. Eval. Res. Educ., vol. 9, no. 4, pp. 881-886, 2020, doi: 10.11591/ijere.v9i4.20766.

[6] N. F. Amin, A. A. Latif, M. Arsat, N. Suhairom, N. F. Jumaat, and M. E. Ismail, "The implementation of the internship as a coursework in teaching and learning vocational education," $J$. Tech. Educ. Train., vol. 12, no. 1 Special Issue, pp. 82-90, 2020, doi: 10.30880/jtet.2020.12.01.009.

[7] N. Usman, A. R. Murniati, Z. A. Tabrani, and Syahril, "The implementation of Total Quality Management (TQM) at National Vocational Schools (SMKS) in Aceh, Indonesia," Talent Dev. Excell., vol. 12, no. SpecialIssue2, pp. 664-672, 2020.

[8] Wagiran, Pardjono, and H. Sofyan, "What industry needs of vocational school graduate competence in the era of industrial revolution 4.0," Int. J. Adv. Sci. Technol., vol. 29, no. 5, pp. 2459-2470, 2020.

[9] S. N. Abdul-Aziz, N. Zulkifli, I. M. Nashir, and N. A. H. A. Karim, "Pull and push factors of students' enrolment in the tvet programme at community colleges in Malaysia," J. Tech. Educ. Train., vol. 12, no. 1 Special Issue, pp. 68-75, 2020, doi: 10.30880/jtet.2020.12.01.007.

[10] M. B. Triyono, "Tantangan revolusi industri ke 4 (I4.0) bagi pendidikan vokasi," in Seminar Nasional Vokasi dan Teknologi (SEMNASVOKTEK), 2017, pp. 1-5.
[11] M. Santoso et al., Kerangka Kualifikasi Nasional Indonesia. Kementerian Riset, Teknologi, dan Pendidikan Tinggi Republik Indonesia, 2015.

[12] Gunawan, N. M. Y. Suranti, and Fathoroni, "Variations of models and learning platforms for prospective teachers during the COVID-19 pandemic period," Indones. J. Teach. Educ., vol. 1, no. 2, pp. 61-70, 2020.

[13] E. W. Pratiwi, "Dampak Covid-19 terhadap kegiatan pembelajaran online di sebuah perguruan tinggi kristen di Indonesia," Perspekt. Ilmu Pendidik., vol. 34, no. 1, pp. 1-8, 2020, doi: doi.org/10.21009/PIP.341.1 Volume.

[14] Y. T. Hewindati, "Mengelola interaksi pembelajaran online di tengah pandemi Covid-19," 2020.

[15] M. Dickson and S. E. Ladefoged, "Introducing active learning pedagogy into a technical and vocational education and training academy in Kurdistan, Iraq," Int. Rev. Educ., vol. 63, no. 5, pp. 679702, 2017, doi: 10.1007/s11159-0179660-3.

[16] B. M. Salleh, A. Esa, A. Selamat, H. O. A. Sulaiman, and K. A. Suhaimy, "Computer-mediated communication as a tool for improving the english language among adult Learners in TVET programme," J. Tech. Educ. Train., vol. 2, no. 1, pp. 31-41, 2010.

[17] S. Aydin, Y. Akkan, E. Arpaz, and B. Koparan, "learning in vocational school: focus on students' perceptions," Procedia - Soc. Behav. Sci., vol. 174, pp. 3663-3667, 2015, doi: https://doi.org/10.1016/j.sbspro.2015.01. 1087.

[18] H. K. Widyaningrum, C. Hasanudin, A. Fitrianingsih, D. E. Novianti, K. Saddhono, and N. Supratmi, "The use of Edmodo apps in flipped classroom learning. How is the students' creative thinking ability?," Ing. des Syst. d'Information, vol. 25, no. 1, pp. 69-74, 
2020, doi: 10.18280/isi.250109.

[19] N. Roslidah and D. Ferary, "Integrasi TIK dalam Pendidikan Vokasi Inggris," in Sistem Pendidikan Vokasi di Inggris, London: Kantor Atase Pendidikan dan Kebudayaan Kedutaan Besar Republik Indonesia (KBRI), 2018.

[20] Gunawan, N. M. Y. Suranti, and Fathoroni, "Variations of models and learning platforms for prospective teachers during the COVID-19 pandemic period," Indones. J. Teach. Educ., vol. 1, no. 2, pp. 61-70, 2020.

[21] Firman and S. R. Rahman, "Pembelajaran online di tengah pandemi Covid-19," Indones. J. Educ. Sci., vol. 2, no. 2, pp. 81-89, 2020.

[22] B. Azhari and I. Fajri, "Distance learning during the COVID-19 pandemic: School closure in Indonesia," Int. J. Math. Educ. Sci. Technol., pp. 1-21, 2021, doi: 10.1080/0020739X.2021.1875072.

[23] S. Chen and Y. Lu, "The negative effects and control of blended learning in university," in International Conference on Education Technology and Information System, 2013, pp. 28-31.

[24] Kemdikbud, "Pangkalan Data Perguruan Tinggi," Kemdikbud, 2020. .

[25] S. E. Harpe, "How to analyze likert and other rating scale data," Curr. Pharm. Teach. Learn., vol. 7, no. 6, pp. 836-850, 2015, doi: 10.1016/j.cptl.2015.08.001.
[26] J. Hartley, "Some thoughts on likert-type scales," Int. J. Clin. Heal. Psychol., vol. 14, no. 1, pp. 83-86, 2014, doi: 10.1016/S1697-2600(14)70040-7.

[27] U. Rahardja, N. Lutfiani, and R. Rahmawati, "Student Perception to the News on the APTISI website," J. Ilm. SISFOTENIKA, vol. 8, no. 2, pp. $117-$ 127, 2018

[28] B. Surkhali and C. K. Garbuja, "Virtual learning during COVID-19 pandemic: Pros and cons," J. Lumbini Med. Coll., vol. 8, no. 1, 2020, doi: https://doi.org/10.22502/jlmc.v8i1.345.

[29] D. Nambiar, "The impact of online learning during COVID-19: students' and teachers' perspective," Int. J. Indian Psychol., vol. 8, no. 2, 2020, doi: 10.25215/0802.094.

[30] J. C. Yeung, K. Fung, and T. D. Wilson, "Prospective evaluation of a web-based three-dimensional cranial nerve simulation," J. Otolaryngol. - Head Neck Surg., vol. 41, no. 6, pp. 426-436, Dec. 2012, doi: 10.2310/7070.2012.00049.

[31] M. Kris Yuan Hidayatulloh and Ö. Çobanoğlu, "The effect of problem-based learning model and blended learning model to metacognitive awareness as a reflection towards a new normal era," $J$. Pendidik. Teknol. dan Kejuru., vol. 26, no. 2, pp. 183-188, Sep. 2020, doi: 10.21831/jptk.v26i2.32783. 